\title{
IFRS Adoption and Timeliness of Financial Reporting of Insurance Firms in Nigeria
}

\author{
Gospel J. Chukwu ${ }^{1 *}$, Aloy-Ezirim, Helen Nkechinyere ${ }^{2}$ \\ ${ }^{I}$ Department of Accounting, Federal University Otuoke, Bayelsa State, Nigeria \\ ${ }^{2}$ Department of Accounting, Ignatius Ajuru University of Education, Rumuolumeni, Port Harcourt, Nigeria \\ *Corresponding Author: Gospel J. Chukwu, Department of Accounting, Federal University Otuoke, \\ Bayelsa State, Nigeria
}

\begin{abstract}
The objective of this study is to investigate the extent to which the mandatory adoption of IFRS affects timeliness of financial reporting in the insurance industry in Nigeria. The study used the ex-post facto design, and data from 18 insurance firms listed on the Nigerian Stock Exchange, for the period 2010 to 2013. Timeliness in financial reporting was measured using audit lag, and five control variables (profitability, firm size, leverage, board size and board independence) were introduced into the regression model used in analysing the data. Results indicate that mandatory IFRS adoption by insurance firms in Nigeria did not significantly affect the timeliness of financial reporting in that industry. This is possibly because the rigorous implementation of IFRS is still a challenge in the insurance industry in Nigeria. A recent manifestation of this problem is the argument by the external auditors of some insurance firms that the implementation of IFRS 9 will delay the timely completion of 2018 financial statements. The implication is that insurance firms and regulators in the industry should continue to focus on developing IFRS accounting and auditing capacity in the industry.
\end{abstract}

Keywords: Timeliness; Audit Lag; IFRS Adoption; Insurance Industry

\section{INTRODUCTION}

The mandatory adoption of International Financial Reporting Standards (IFRS) in the European Union in 2005 as the preferred accounting regime triggered rapid world-wide adoption of IFRS. In its 2019 report on the global status of IFRS adoption worldwide, the International Federation of Accountants (IFAC) observed that over 120 countries have adopted IFRS as the basis for financial reporting in their jurisdictions [1]. Nigeria mandatorily adopted IFRS on 1 January, 2012, and directed entities of substantial public interest (such as publicly listed firms) to comply with the new standards with effect from that date. To help enforce the standards and improve the quality of financial reporting in the country, the Federal Government established the Financial Reporting Council of Nigeria. The change in accounting regime was expected to positively affect financial reporting practices in the country in a number of ways.

A large stream of research has examined the consequences of IFRS adoption on earnings management [2], value relevance [3], foreign investment inflow [4], comparability of financial reports [5], timely loss recognition [6], and timeliness in financial reporting [7]. Timeliness is an important qualitative characteristic of financial reporting that enhances the relevance of financial information. The International Accounting Standard Board (IASB) defines timeliness as having information available in such timely manner that it can influence decisions. The IASB argues that generally, information becomes less useful with the passage of time except the information is used in determining trends or for confirmatory purposes. Accordingly, the IASB encourages preparers and users of financial statements to maximize the use of this characteristic which enhances the usefulness of financial information [8].To ensure timeliness in financial reporting, regulators usually set time lines for submission of quarterly and annual reports. Firms that fail to submit their quarterly and annual reports at stipulated times are penalized by the regulators.

Studies that examined how mandatory implementation of IFRS affects the timeliness of financial reporting in the insurance industry in Nigeria are scanty. Chukwu and Okoye [6], for instance, examined how the adoption of IFRS in Nigeria affects timely loss recognition, using data from 54 
firms in Nigeria and 96 firms in South Africa. The study excluded firms in the financial sector of both countries. Fodio, Oba, Olukoya and Zik-rullahi [9] conducted a study on IFRS adoption and audit timeliness, using data from Nigerian banks. Oshodin and Ikhatua [7] investigated the relationship between IFRS implementation and financial reporting timeliness, using data from 30 firms which were purposively selected. The study did not show the industry classification of these firms. Since industry classification is one of the factors that consistently affects timeliness of financial reporting [10], and prior studies provide scanty evidence from the insurance industry; accordingly, there is a research gap which this study intends to fill.

The focus on the Nigerian insurance industry is justified for a number of other reasons. Insurance companies promote socio-economic activities through risk transfer and indemnification of companies and individuals. Unfortunately, insurance penetration in Nigeria is poor [11] and equity investors in Nigeria have poor perception about the industry [12]. Research findings on timely availability of financial information in the insurance industry may help regulators in improving financial reporting quality and investors' perception towards the industry.

The rest of the paper is organized as follows: section 2 presents literature review while section 3 discusses the research methodology. The results are shown in section 4 and discussed in section 5, while section 6 presents the recommendations.

\section{REVIEW OF RELATED LITERATURE}

\subsection{Insurance Industry in Nigeria and IFRS Adoption}

The history of insurance activities in Nigeria dates back to when the Royal Exchange Assurance Agency formally commenced operations in 1918 [13]. As at December 31, 2015 there were fifty insurance firms in Nigeria and twenty eight were listed on the Nigerian Stock Exchange. The National Insurance Commission (NAICOM) was established in accordance with the provisions of the Insurance Act, 2003 as the apex regulator of the insurance industry in Nigeria. However, insurance firms are required to comply with the financial reporting requirements set forth in the Companies and Allied Matters Act (CAMA) and the Listing Rules of the Nigerian Stock Exchange for listed entities. As in other countries, insurance firms act as financial intermediaries in the Nigerian financial services sector. They promote the culture of savings and fund mobilization thereby facilitating the socioeconomic development of the country.

Following the World Bank reports of 2004 and 2011 which found significant deficiencies in corporate financial reporting in Nigeria, the Federal Government set up the committee on Road Map to the adoption of International Financial Reporting Standards in Nigeria. In 2010 the Federal Government of Nigeria approved the recommendation of the Committee for the mandatory adoption of IFRS in Nigeria effective 1 January, 2012. It subsequently enacted the Financial Reporting Council Act in 2011. The Act established the Financial Reporting Council to replace the Nigerian Accounting Standards Board. Thus the mandatory adoption of IFRS in Nigeria began on January 1, 2012. Insurance firms listed on the Nigerian Stock Exchange, as well as other listed firms, commenced the implementation of IFRS (as issued by the International Accounting Standards Board) with effect from that date.

\subsection{Conceptual Review}

IFRSs are regarded as high quality standards and their rigorous implementation is expected to scale up the quality of financial reporting in an accounting jurisdiction. To guide IFRS adopters in improving the quality of their financial reporting, the IASB published a Conceptual Framework that sets out qualities of useful financial reports. One of the features that enhance the relevance of financial information is timeliness - the availability of information to decision makers timely enough for useful decision making. In its Basis for Conclusion, the IASB noted that timeliness is desirable, especially when such information is relevant for decision making. Except when information is confirmatory or desired to establish a trend, timeliness should be ensured if the objective of decision making is to be met. The regulatory framework sets the dead line for submission and publication of audited financial statements. The companies act (CAMA) set a deadline of six months after year end. Timeliness is of great significance to investors since it curtails information asymmetry [14] and promotes market discipline through reduction in information leakages, rumours and insider abuses [15, 16]. Timeliness can affect the uncertainty level of the decision makers' choices as well as security prices [17]. 


\subsection{Empirical Review}

Stakeholders are interested in ascertaining factors enhancing or inhibiting timeliness. Extant literature has identified some of the factors as firm size, profitability, leverage, quality of internal control, financial conditions, audit risks, audit complexity, and industry classification $[10,14,16,18,19,20,21,22]$. Soderstrom and Sun [23] argue that the accounting standard being followed affects financial reporting practices. IFRS is credited with demanding more extensive disclosures than the domestic GAAP [24]. This entails more audit work and consequent delay in timely completion of the audit.

Furthermore, IFRS is characterized by the use of fair values. Financial statements characterized by use of fair values pose great challenges to the auditors [25]. This is because auditors have limited understanding of valuation techniques used in determining fair values. Martin et al [25] further argue that the internal control environment for fair value measures is different and internal controls over fair value measurements are more difficult to understand. This suggests increase in audit complexity which ultimately is likely to negatively affect timely completion of audit. De George, Ferguson, \& Spear [26] provide evidence of audit complexity arising from IFRS adoption as they lead to a significant increase in audit fees of industrial firms in Australia. Ajekwe, Onobi, and Ibiamke [27] examine the effect of IFRS adoption on audit fees of Nigerian deposit banks and find that audit complexity is significantly different between pre and post IFRS period.

Fodio et al. [9] report that IFRS adoption in Nigeria is positively associated with timeliness of financial reporting in the country. The study attributed the result to increase in complexity associated with accounting under IFRS, and the consequent audit reporting lag. Oshodin and Ikhatua [7] report a negative coefficient on the variable for IFRS adoption and a moderately significant $p$ value, suggesting that the adoption of IFRS slightly increased the timeliness of financial reporting in Nigeria. Contrarily, Chukwu and Okoye [6] document that the implementation of IFRS in Nigeria and South Africa did not significantly affect timely loss recognition in the two countries, due possibly to weaknesses in the enforcement of the standards. So far, the results from prior studies are mixed.

Based on the above discussion, the study presents the following hypothesis in the null form.

Ho: There is no significant difference in timeliness of corporate financial reporting of insurance firms between pre IFRS period and post IFRS period.

\subsection{Theoretical Framework}

This study is guided by the agency theory and resource dependency theory. According to the IASB Conceptual Framework, financial reports should help present and potential investors and stakeholders to make informed investment decisions about the timing and uncertainty of the reporting entity's cash inflows and cash outflows. This is possible if financial statements possess the qualitative characteristic of timeliness. Timeliness means availability of information needed by decision makers for useful decision making before it loses its capacity to influence decision. Timeliness is necessary to alleviate information asymmetry. Under the agency relationship, the owners (shareholders) delegate day to day management of the firm to the managers (agents). The managers consequently have information advantage over the shareholders. This information advantage is termed information asymmetry[28,29].To reduce information asymmetry between managers and other stakeholders, boards can compel managers to comply with policies on reporting timeliness by insisting that reports be submitted early enough for board deliberations and ratification. How effective such board actions will be will depend on the institutional context of the firm.

Another important determinant of organizational success is the resources on which the organization uses to reduce dependence and uncertainties in the external environment. One of the approaches suggested by Pfeffer and Salancik [30] for reducing external dependences is the use of board of directors [31]. Therefore, the level of resources available in board of directors can affect firm success.

IFRS changes occur every now and then, and the rigorous implementation of these standards will depend on the knowledge capacity of the financial statement preparers, the effectiveness of the board and the regulators of insurance firms.

\section{Methodology}

\subsection{Research Design and Data}

The study used the ex-post facto design as the observations used in the research were established before the research. The study covers a period of four years, 2010 to 2013, two years before IFRS 
adoption in the Nigeria and the first two years of adopting the new financial reporting regime. The choice of the period is to capture the direct effect of the IFRS adoption on timeliness.

The data for the study were obtained from the annual reports of insurance firms listed on the Nigerian Stock Exchange. The annual reports were obtained from the Library of the Nigerian Stock Exchange in Port Harcourt, Nigeria.

\subsection{Population and Sample}

The Fact Book of the Nigerian Stock Exchange shows that twenty eight insurance firms were listed on the Stock Exchange at $31^{\text {st }}$ December, 2013. This number therefore constitutes the population of the study. Using Taro Yamene's formula, gives a sample size of twenty six. Eight firms were excluded from the sample because of incomplete information; therefore the final sample is eighteen insurance firms and 72 firm-year observations for the period 2010 to 2013. The Taro Yemene's formula is given as follows:

$$
n=\frac{N}{1+(e)^{2}}
$$

Where:

$\mathrm{n}=$ sample size sought

$\mathrm{e}=$ level of significance

$\mathrm{N}=$ Population size

Table1. Sample selection procedure

\begin{tabular}{|l|l|l|}
\hline Description & No of firms & Firm year observations \\
\hline Population & 28 & 112 \\
\hline Sample size & 26 & 104 \\
\hline Less firms with incomplete data & 8 & 32 \\
\hline Final sample & 18 & 72 \\
\hline
\end{tabular}

\subsection{Empirical Model}

The study models timeliness as a function of mandatory IFRS adoption and control variables. The model is:

AUDLAG $=f($ POST, PROF, SZE, LEV, BODSZE, BODIN).

Explicitly the model is stated thus:

$$
\begin{array}{ll}
\text { AUDLAG }_{\mathrm{i}, \mathrm{t}} & =\beta_{0+} \beta_{1} \mathrm{POST}_{\mathrm{i}, \mathrm{t}}+\beta_{2} \mathrm{PROF}_{\mathrm{i}, \mathrm{t}}+\beta_{3} \mathrm{SZE}_{\mathrm{i}, \mathrm{t}}+\beta_{4} \mathrm{LEV}_{\mathrm{i}, \mathrm{t}}+\quad \beta_{5} \text { BODSZE }_{\mathrm{i}, \mathrm{t}}+ \\
& \beta_{6} \text { BODIN }_{\mathrm{i}, \mathrm{t}}+\varepsilon_{\mathrm{i}}
\end{array}
$$

Where for insurance firm $\mathrm{i}$ at year $\mathrm{t}$ :

\begin{tabular}{|l|l|l|}
\hline AUDLAG & $=$ & $\begin{array}{l}\text { audit lag as a measure of timeliness. Measured as the number of days } \\
\text { between the year-end date and the date the auditor signs the audit report. }\end{array}$ \\
\hline POST & $=$ & $\begin{array}{l}\text { a dummy variable coded } 1 \text { if the observation falls in the mandatory adoption } \\
\text { period, (2012 to 2013) and } 0 \text { otherwise. }\end{array}$ \\
\hline PROF & $=$ & net profit or loss reported by the firm \\
\hline SZE & $=$ & size measured as natural log of total assets \\
\hline LEV & $=$ & board size, measured by the number of directors \\
\hline BODSZE & $=$ & board independence measured by the proportion of non-executive directors \\
\hline BODIN & $=$ & error term \\
\hline$\varepsilon$ &
\end{tabular}




\begin{tabular}{|l|l|l|}
\hline$\beta_{0}$ & $=$ & Intercept \\
\hline$B_{1} \ldots \ldots \beta_{6}$ & $=$ & regression coefficients \\
\hline
\end{tabular}

The model contains five control variables - profitability, firm size, leverage, board size, and board independence.

Profitability

Auditors perceive profitable firms to be less risky than loss firms [32]. Therefore, the auditor would conduct less audit tests for profitable firmsthan for loss firms. Consequently a negative association between profitability and audit lagis expected. Prior studies confirm the existence of a negative relationship between profitability and audit lag [21]; and this indicates that profitable firms issue financial reports on a more timely basis, possibly to quickly communicate their good performance to investors.

Firm size

Large firms have more resources than smaller firms and are therefore more likely to establish and maintain effective and adequate internal control system. Furthermore large firms face more intense scrutiny from stakeholders [33].Thus firm size is expected to have negative association with audit lag.

Leverage

It is argued that highly geared firms have incentives to ensure timely completion of audit and release of financial statements because they face intense scrutiny and pressure from debt holders and regulators [34]. It is also possible for highly geared firms to delay financial reporting because auditors may spend time confirming the valuation of debts to avoid misleading the investing public. The study therefore predicts a positive association between leverage and audit reporting lag.

Board size and board independence

Prior studies show that firms with large board size benefit from large pool of expertise in ensuring effective monitoring of the financial reporting processes [35]. Equally, a highly independent board has been found to achieve control over the financial reporting processes [36]. Effective internal control facilitates timely completion of external audit work. Hence a negative association is predicted between board size and audit lag. Similarly, a negative relationship between independence and audit lag is expected; in order words, board size as well as board independence is expected to affect timeliness in financial reporting, positively.

\section{Results}

\subsection{Descriptive Statistics}

Table 2 and Table 3present the descriptive statistics of the study. Table 2 shows the mean reporting days of 201 days after year end. The reporting days after year end range from 54 days to 976 days. Analysis based on the pre and post IFRS period presented in Table 3shows a mean reporting lag of 172 days in the pre IFRS period compared to 229 days in the post IFRS days. Though the mean lag reporting days in the Pre IFRS period was within the period allowed by the company Act, it is not significantly different from that of post IFRS years $(p$-value $=9.097)$. A number of insurance firms fail to comply with the provisions of the act in terms of timeliness in financial reporting, especially in the post IFRS period. The implication is that most of the sampled insurance firms deny users of financial statements information needed for making rational decisions, on a timely basis.

Table2. Descriptive Statistics (overall sample)

\begin{tabular}{|l|l|l|l|l|l|}
\hline Variable & Obs & Mean & Std. Dev. & Min & Max \\
\hline Audlag & 72 & 201.1944 & 148.1857 & 54 & 976 \\
\hline Sze & 72 & 354599 & 1418805 & 2609.44 & 6677772 \\
\hline Prof & 72 & 8642.511 & 60770.09 & -178195 & 396139.8 \\
\hline Lev & 72 & .5381922 & .3172304 & .0911242 & 1.929888 \\
\hline Bodsze & 72 & 9.041667 & 1.15597 & 6 & 11 \\
\hline Bodin & 72 & .7389083 & .1687639 & .1111 & .9 \\
\hline
\end{tabular}


IFRS Adoption and Timeliness of Financial Reporting of Insurance Firms in Nigeria

Table3. Descriptive statistics - Pre versus Post IFRS Period

\begin{tabular}{|l|l|l|l|l|l|}
\hline & & Pre IFRS & Post IFR & Mean Difference \\
\hline Variable & Obs & Mean & Mean & Z & p-value \\
\hline Audlag & 36 & 172 & 229.8333 & 1.660046 & 9.097 \\
\hline Size & 36 & 338266.7 & 370931.2 & 0.096993 & 9.9282 \\
\hline Profit & 36 & 10674.56 & 6610.459 & -0.28189 & 9.7794 \\
\hline Lev & 36 & .3333333 & .6388889 & 2.296513 & 9.0214 \\
\hline Bodsze & 36 & 9.027778 & 9.055556 & 0.101238 & 9.9124 \\
\hline Bodin & 36 & .9444444 & .9444444 & 0 & 1 \\
\hline
\end{tabular}

\subsection{Bivariate Analysis}

A correlational analysis between the dependent and independent variables is displayed in Table 4 . IFRS exhibit positive correlation with audit lag, our measure of timeliness. Firm size and board size show statistically negative correlation with audit lag. The highest correlation among the variables is 60 percent and the variance inflation factor for each variable (see Table 5) is below the threshold of 10 , suggesting that multicollinearity is not a serious problem in the study [37].

Table4. Correlation matrix

\begin{tabular}{|l|l|l|l|l|l|l|l|}
\hline & Audlag & Post & Prof & Sze & Lev & Bodsze & Bodin \\
\hline Audlag & 1.0000 & & & & & & \\
\hline Post & 0.1946 & 1.0000 & & & & & \\
\hline Prof & -0.1383 & -0.0337 & 1.0000 & & & & \\
\hline Sze & $-0.2567^{*}$ & 0.0385 & $0.5348^{*}$ & 1.0000 & & & \\
\hline Lev & $0.6097^{*}$ & 0.1994 & -0.0850 & -0.2244 & 1.0000 & & \\
\hline Bodsze & $-0.5361^{*}$ & 0.0121 & 0.0878 & 0.1488 & -0.1576 & 1.0000 & \\
\hline Bodin & 0.1900 & -0.0372 & $-0.5282^{*}$ & $-0.8266^{*}$ & 0.1163 & -0.0018 & 1.0000 \\
\hline
\end{tabular}

* indicates $5 \%$ level of significance.

\subsection{Multivariate Analysis}

The result of test of hypothesis is presented in Table 5. The table shows that the model fits the variables excellently $(\mathrm{F}$ statistic $=10.61 ; \mathrm{p}$-value $=0.0000)$. Table 5 further reveals that $60 \%$ of the variations in timeliness is explained by the independent variables while the remainder is captured by the error term.

Table5. Regression results

\begin{tabular}{|l|l|l|l|l|l|l|l|}
\hline Audlag & Coef. & Robust Std. Err. & $\mathrm{T}$ & $\mathrm{P}>|\mathrm{t}|$ & VIF & \multicolumn{2}{l|}{ Summary } \\
\hline Post & 30.2900 & 28.0362 & 1.08 & 0.284 & 1.06 & Observations & 72 \\
\hline Prof & $3.49 \mathrm{e}-08$ & $1.42 \mathrm{e}-07$ & 0.25 & 0.806 & 1.46 & $\mathrm{~F}(6,65)$ & 10.6 \\
\hline Sze & 10.0059 & 11.0432 & 0.91 & 0.368 & 3.67 & Prob $>\mathrm{F}$ & 0.00 \\
\hline Lev & 239.683 & 78.6527 & 3.05 & 0.003 & 1.14 & $\mathrm{R}^{2}$ & 0.60 \\
\hline Bodsze & -60.655 & 10.2667 & -5.91 & 0.000 & 1.09 & Root MSE & 97.8 \\
\hline Bodin & 200.678 & 117.351 & 1.71 & 0.092 & 3.47 & Mean VIF & 1.98 \\
\hline Cons & 290.984 & 258.122 & 1.13 & 0.264 & & & \\
\hline
\end{tabular}

\section{DISCUSSION OF RESULTS}

\subsection{Mandatory IFRS Adoption and Timeliness}

Ho1 tested the relationship between mandatory IFRS adoption and timeliness. Table 5 shows that POST (the variable for IFRS adoption) has a positive coefficient $\left(\beta_{1}=30.29003\right)$. This suggests that audit lag increases with the mandatory adoption of IFRS. The result supports the view that IFRS reporting consumes more audit time than the reporting regime based on domestic standards. This situation is possibly because IFRS requires more disclosures and uses more complicated valuation bases, such as the fair value approach [26]. However, the relationship between IFRS adoption and timeliness in financial reporting in the insurance industry in Nigeria is not significant at any of the conventional levels ( $\mathrm{p}$-value $=0.284$ ). This finding supports the null hypothesis which states that there is no significant relationship between mandatory IFRS adoption and timeliness in corporate financial reporting. The finding is consistent with Chukwu and Okoye [6] who documented an insignificant relationship between IFRS adoption and timely loss recognition in Nigeria and South Africa. The 
finding of the current study is possibly due to the vast and dynamic requirements of IFRS accounting, which engages financial reporting capacity of preparers of financial statements in the insurance industry and theirexternal auditors. For instance, the Nigerian Insurance Commission (regulators of insurance firms in Nigeria) mandated insurance firms to implement IFRS 9, Financial Instruments, and the amendment to IFRS 4 (Insurance Contracts), but some external auditors in the insurance industry complained that implementing the IFRSs in 2018 will delay the completion of the 2018 audited financial statements [38]. Thus, despite improvements in the regulatory environment in the IFRS regime, timeliness in financial reporting did not improve in the insurance industry in Nigeria.

\subsection{Control Variables and Timeliness}

Profitability and size of insurance firms show no significant association with timeliness. Leverage is positively and significantly related to audit lag $\left(\beta_{1}=239.6832\right.$ : $p$-value $\left.=0.003\right)$, suggesting that firms that use more of debt than equity financing experience less timely financial reporting. This finding is consistent with Ebirien [39]. However, the finding is not consistent with the line of literature that suggests that leverage will be positively associated with timeliness since the affairs of more highly geared firms will be subject to greater scrutiny by debt holders [34]. The findings of this study may be attributed to the fact that more highly geared insurance firms may pose greater risk to the external auditors than the firms with relatively low gearing. Thus, the external auditor may take more time to verify the values disclosed. Also, the more highly geared firm may be reluctant to quickly issue their financial statements since relying more on debt than other competitors in the industry may be perceived as poor performance by investors. Similarly, board independence reveals a statistically significant and positive association with audit lag (p-value 0.092), indicating that independent board members do not contribute significantly in improving timeliness of financial reporting. This contradicts our a priori expectation that an independent board is an effective monitor of the financial reporting process. However, board size shows significant negative relationship with audit lag, suggesting that the size of the board positively affects timeliness in financial reporting. This is consistent with resource dependence theory.

\section{CONCLUSION AND RECOMMENDATION}

The study investigated the extent to which the mandatory adoption of IFRS affects timeliness in financial reporting in the insurance industry. One hypothesis was formulated and tested. The result from the ordinary least square regression indicates that the mandatory IFRS in Nigeria did not improve timeliness in financial reporting in the insurance industry. This result may be attributed to the difficulties in grappling with IFRS requirements in the insurance industry and the feeling that implementing some of these standards is burdensome. The current complain in the insurance industry in Nigeria that implementing IFRS 9 is a burden [38] supports this view.

More enlightenment and coercive pressures may be needed to achieve rigorous implementation of applicable IFRS in the insurance industry in Nigeria.

Further studies may analyze how insurance industry attributes like insurance contract, insurance liabilities, and margin of safety affect timeliness in financial reporting.

\section{REFERENCES}

[1] IFAC (2019). International Standards: 2019 Global Status Report. Retrieved from https://www.ifac.org $>$ system $>$ files $>$ publications $>$ files $>$ IFAC

[2] Capkun, V., Collins, D., Jeanjean, T. (2016). The effect of IAS/IFRS adoption on earnings management (smoothing): A closer look at competing explanations. Journal of Accounting and public Policy, 35(4), 352-394

[3] Chukwu, G.J., Damiebi, I. J., \& Okoye, E.I. (2019). Firm-Specific Attributes and the Value Relevance of Accounting Information in Nigeria. International Journal of Business and Management, 14(10), 12-20

[4] Jinadu, O., Ojeka, S., \& Ibidunni, O.M. (2016). IFRS adoption and foreign direct investment: Evidence from quoted Nigerian firms. Mediterranean Journal of Social Sciences, 7(2), 99-105

[5] Yip, R.W.Y. \& Young, D. (2012). Does mandatory IFRS adoption improve information comparability. The Accounting Review, 1767-1789

[6] Chukwu, G.J. \& Okoye, E.I. (2016). Mandatory Adoption of International Financial Reporting Standards and Timely Loss Recognition. Evidence from Nigeria and South Africa. ICAN Journal of Accounting \& Finance (Academic Conference Special Edition) 1(1), 59 - 70 
[7] Oshodin, E. \& Ikhahua, J.O. (2018). IFRS adoption, firms' characteristics and the timeliness of financial information. International Accounting and Taxation Research Group, 2(1), 92-106

[8] IASB (2018), IFRS Standards: Issued at 1 January 2018. London: IFRS Foundation.

[9] Fodio, M.I., Oba, V.C., Olukoja, A.R., \& Ahmed, A.Z. (2015). IFRS adoption, firm traits and audit timeliness: Evidence from Nigeria. ACTA Universitas Danubius Economica, 11(3), 106-119

[10] Ashton, R.H, Graul, P.R., \& Newton, J.D. (1989). Audit delay and the timeliness of corporate reporting, Contemporary Accounting Research,5(2): 657-673.

[11] Chukwu, G.J. \& Obah, G.W. (2019). Impairment charges and market value of insurance firms in Nigeria. International Journal of Business and Management, 14(4), 171-181

[12] Chukwu, A.N., Obara, L.C., \& Chukwu, G.J. (2016). Earnings smoothing and performance of insurance firms in Nigeria, Accounting Education, Research and Practice. Nigerian Accounting Association Conference Proceedings, 81-91

[13] Jegede, M. (2005). A comprehensive analysis of the Insurance Act 2003 and its implications on the Insurance Business Environment, Issues in Merger and Acquisition for the Insurance Industry. Pp. 61-78 (ed) Ezekiel, O. C. Being proceeding of the 2003 NIA Workshop on Insurance Act 2003. Nigeria Insurance Association.

[14] Jaggi, B. and Tsui, J. (1999). Determinants of audit report lag: Further evidence from Hong Kong, Accounting and Business Research, 30(1), 17-28.

[15] Ismail, K.N.I.K., \& Chandler, R. (2003). The timeliness of quarterly financial reports of companies in Malaysia. Retrieved from https://ssrn.com/abstract=415047

[16] Leventis, S., Weetman, P. \& Caramanis, C. (2005). Determinants of audit report lag: Some evidence from the Athens Stock Exchange, International Journal of Auditing, 9(1), 45-58.

[17] Ashton, R.H, Willingham, J.J., \& Elliot, R.R. (1987). An empirical analysis of audit delay, Journal of Accounting Research, 25(2), 275-292.

[18] Ahmed, K (2003). A comparative study of timeliness of corporate financial reporting in South Asia, Advances in International Accounting, 16, 17-42.

[19] Imam S, Ahmed, Z.U. and Khan, S.H. (2001). Association of audit delay and audit firms' International links: Evidence from Bangladesh, Managerial Auditing Journal, 16(3), 129-133.

[20] Knechel, W R and Payne, J L (2001) . Additional evidence on audit report lag, Auditing: A Journal of Practice \& Theory, 20(1), 137146.

[21] Owusu-Ansah, S. (2000). Timeliness of corporate financial reporting in emerging capital markets: Empirical evidence from Zimbabwe Stock Exchange, Accounting and Business Research, 30(3), 241-254.

[22] Soltani, B. (2002). Timeliness of corporate and audit reports: Some empirical evidence in the French context, The International Journal of Accounting, 37, 215-246.

[23] Soderstrom, N. S., \& Sun, K. J. (2007). IFRS adoption and accounting quality: A review, European Accounting Review, 16(4), 675-702.

[24] Ball, R. (2006). International Financial Reporting Standards (IFRS): pros and cons for investors, Accounting and Business Research, International Accounting Policy Forum, 5-27.

[25] Martin, R. D., Rich, J. S., \& Wilks, T. J. (2006). Auditing fair value measurements: synthesis of relevant research, Accounting Horizons, 20(3), 287-303.

[26] De-George, E. T., Ferguson, C. B., \& Spear, N. A. (2013). How much does IFRS cost? IFRS adoption and audit Fees. The Accounting Review, 88(2), 429-462.

[27] Ajekwe, C. C. M., Onobi, S. D., \& Ibiamke, A. (2017). Effect of IFRS adoption on audit fees of listed deposit money banks in Nigeria, European Journal of Accounting Auditing and Finance Research, 5(6), 77-87.

[28] Brown, S., \& Hillegeist, S. A. (2007). How disclosure quality affects the level of information asymmetry, Review of Accounting Studies, 12, 443-477.

[29] Healy P., \& Palepu K., G. (2001). Information asymmetry, corporate disclosure, and the capital markets: A review of the empirical disclosure literature, Journal of accounting and economics, 31(1), 405-440.

[30] Pfeffer, J., \& Salancik, G.R. (1978). The External Controls of Organizations: A Resource Dependence Perspective. New York: Haper \& Row

[31] Hillman, A.J., Withers, M.C. \& Collins, B.J. (2009). Resource dependence theory: A review. Journal of Management, 35(6), 1404-1427

[32] Givoly, D \& Palmon, D (1982). Timeliness of annual earnings announcements: Some empirical evidence, Accounting Review (July), 486-508.

[33] Watts, R., \& Zimmerman. J. (1986). Positive Accounting Theory, Englewood Cliffs, NJ: Prentice Hall 
[34] Simnett, R (1995). Determinants of audit delay, Advances in Accounting, Greenwich, 13, 1- 26.

[35] Klein, A. (2002). Audit committee, board of director characteristics, and earnings management, Journal of Accounting and Economics, 33, 375-400.

[36] Agrawal, A., \& Chadha, S. (2005). Corporate governance and accounting scandals, Journal of Law \& Economics, 48 (2), 371-406.

[37] Hair, J. F., Black, W. C., Babin, B. J., \& Anderson, R. E. (2010). Multivariate Data Analysis: A Global Perspective (7th ed.), Upper Saddle River, New Jersey: Pearson Prentice Hall:

[38] Onuoha, R. (2019). IFRS 9 implementation burdens insurance firms. Retrieved from vanguardngr.com/ 2019/ifrs-9-implementation-burdens-insurance-firms/

[39] Ebirien, G. I. (2014). The effect of mandatory adoption of uniform year end date on timeliness of corporate financial reporting: Evidence from the Nigerian banking sector. African Journal of Professional Research in Human Development, 10(1), 47-57.

Citation: Gospel J. Chukwu, Aloy-Ezirim, Helen Nkechinyere. "IFRS Adoption and Timeliness of Financial Reporting of Insurance Firms in Nigeria" International Journal of Managerial Studies and Research (IJMSR), vol 8, no. 5, 2020, pp. 1-9. doi: http:// dx.doi.org/10.20431/2349-0349.0805001.

Copyright: () 2020 Authors. This is an open-access article distributed under the terms of the Creative Commons Attribution License, which permits unrestricted use, distribution, and reproduction in any medium, provided the original author and source are credited. 